\title{
DROUGHT EFFECTS ON LEAF CANOPY TEMPERATURE AND LEAF SENESCENCE IN BARLEY
}

\author{
Y. A. Mahmood \\ Lecturer \\ University of Garmian, Kurdistan region, Iraq \\ E-mail: yadgar.mahmood@garmian.edu.krd
}

\begin{abstract}
Drought stress is a major threat on most of the agricultural crops grown in the East Mediterranean Region in the consequence of predicted global climate change (1). Therefore, improving essential cereal crops such as barley is extremely important for this region to increase yield production due to its economic interest and adaptability to dry environments (29). This two-year experiment was carried out in Kalar technical institute, in Garmian region, Iraq during the seasons of 2016-17 and 2017-18. Canopy temperature depression (CTd) and leaf senescence traits (Onset of leaf senescence (SENonset) and End of leaf senescence (SENend)) were evaluated under irrigated and rain-fed conditions for five hybrid genotypes of barley. Canopy temperature was increased by drought by almost one degree Celsius on average for both years $(P=0.002)$. Leaf senescence durations were also affected by water stress and advanced SENonset by around $34 \%(\mathrm{P}=0.001)$ and SENend by around $10 \%$ $(\mathrm{P}=0.01)$ averaging over years. Genotypes $3 / / 14$ scored the highest canopy temperature depression and the latest onset of leaf senescence under drought for the cross year mean $(P=0.05)$. Genotype $3 / / 5$ was also the latest to reach the end of leaf senescence averaging over years. Genotypes $3 / / 14,3 / / 5$ and $3 / / 4$ were generally appeared to have cooler canopy and later onset of leaf senescence than the genotypes $3 / / 18$ and $3 / / 1$ indicating the capability of these genotypes to have a better performance under water limitations comparing to other genotypes. Canopy temperature depression was positively associated with onset of leaf senescence under drought conditions averaging over years $\left(R^{2}=0.89 ; P=0.02\right)$, but not under irrigated conditions $\left(R^{2}=0.45 ; P=0.21\right)$. There was also a trend for a positive association between canopy temperature and the end of leaf senescence under drought conditions $\left(R^{2}=0.59 ; P=0.13\right)$ in 2018 . These associations might be linked to genetic variations in water uptake and/or water-use efficiency.
\end{abstract}

Keywords: Barley, breeding tools, crop physiology, drought tolerance, water-use efficiency

محمود

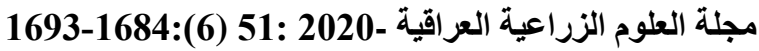

$$
\begin{aligned}
& \text { تأثيرات الجفاف على درجة حرارة الغطاء الخضرى وشيخوخة الاورلق فى الثعير } \\
& \text { يادكار على محمود }
\end{aligned}
$$

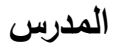

$$
\begin{aligned}
& \text { جامعة كرميان/ اقليم كردستان -العراق }
\end{aligned}
$$

المستخلص

يمثل إجهاد الجفاف تهديدًا كبيرًا على معظم المحاصيل الزراعية التي تزرع في مناطق شرق المتوسط نتيجة للتغيرات المناخ العالمي المتوقع (1). لذلك

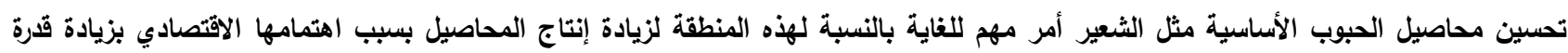
التكيف مع البيئات الجافة (29). تم تنفيذ هذه التجرية التي استغرقت عامين في معهر كلار القني، في منطقة كرميان، العراق خلال مواسم 2016-

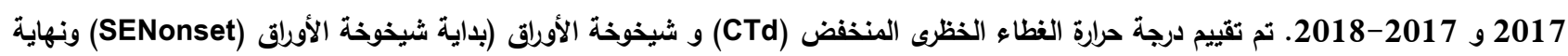
شيخوخة الورقة(SENend) ) تحت ظروفين احدهم مروية وأخرى ديمية بأستخدام خمسة أنماط هجينة من الثعير. زادت درجة حرارة الغطاء الورقي بسبب الجفاف بمقار درجة مئوية واحدة تقريبًا على مستوى معدل العامين (PE = 0.002). تأثرت فترات الثيخوخة الورقية أيضًا بالإجهاد المائي، تقدم 14/3 أعلى انخفاض في درجة حرارة الغطاء الخضرى و اخر من بدأت الثيخوخة الأولق تحت الجفاف على مستوى السنتان (P/3 (P = 0.05). كان النمط

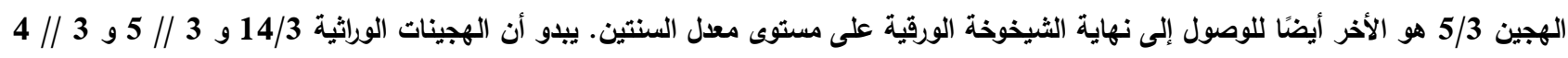

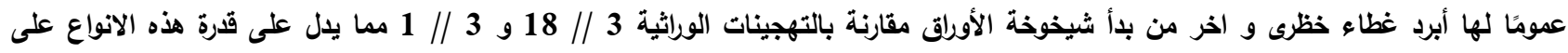
الحصول على أفضل الأداء تحت قلة المياه مقارنة بالتهجينات وراثية أخرى. ارتبط انخفاض درجة دونة حرارة الغطاء الخضرى إيجابيا مع ظهور شيخوخة الورقة تحت ظروف الجفاف على مستوى معدل السنين (

P P2 = 0.21). كان هناك أيضًا اتجاه لوجود علاقة إيجابية بين درجة حرارة الغطاء الخضرى ونهاية شيخوخة الأورلق تحت ظروف الجفاف ( 0.13 = في عام 2018. قد تكون هذه العلاقات مرتبطة بالاختلافات الجينية في قرة امتصاص المياه و / أو كفاءة استخدام المياه. الكلمات المفتاحية: الثعير، أدوات التربية، فسيولوجيا المحاصيل، تحمل الجفاف، كفاءة استخدام المياه

*Received:2/12/2019, Accepted:6/2/2020 


\section{INTRODUCTION}

Barley (Hordeum vulgare L.) is one of the most important crops in drought prone environments in the world, and considered to be a major cereal crop mainly grown for its grain and vegetative forage for animal feed (22). Barley can grow in a wide range of environmental conditions based on different responses by different varieties of barley under various environments $(10,16)$. Drought globally limits agricultural production and reduces crop yields more than any other abiotic stresses. The main goal of plant breeding is to improve yield under water-stress environments $(9,23,31)$. Drought stress is most limiting yield potential under Mediterranean conditions due to a combination of some environmental factors such as high temperature, irradiance and low rainfall during the grain filling and grain formation periods of crop growth $(28,30)$. In this kind of environments, rainfall amount is less than $1000 \mathrm{~mm}$, and mostly precipitate in fall and spring (7). This insufficient and irregular rainfall distribution during the grain filling stage can efficiently effect on crop yield performance (26). The most effective way to increase grain yield under drought-prone conditions can be identification of drought tolerance related traits (28). For plant breeders, investigating the mechanism of each trait could be more beneficial than the selection for drought resistance based on grain yield (11). Traits related to water uptake and water-use efficiency could be the most important e.g. canopy temperature, stay-green and leaf senescence parameters (12). Canopy temperature (CT) has been confirmed to be related to stomatal conductance and can be an indirect indicator of plant water uptake capability under drought (5). Positive association between $\mathrm{CT}$ and root length has been reported in wheat by Reynolds et al. (27). Leaf senescence is a process of nutrients remobilization from vegetative leaves and stems to grain yield which can be genetically and environmentally controlled (4, 15). Delaying leaf senescence can extend the period of grain filling and maintain $\mathrm{CO}_{2}$ assimilation to increase grain yield (33). Therefore, identifying genetic variations and understanding the physiological mechanisms of drought tolerance related traits such as canopy temperature and leaf senescence were the main objectives of this study under wellwatered and unirrigated conditions using five hybrid genotypes of two-rowed barley.

\section{MATERIALS AND METHODS}

\section{Site conditions and Plant materials}

Field experiments were carried out for two seasons (2016 - 2017; referred hereafter as 2017) and (2017 - 2018; referred hereafter as 2018) at Kalar technical institute, As Sulaymaniyah, KRG, Iraq. The site is located at longitude line $45^{\circ} 22^{\prime} 681^{\prime \prime}$ eastern and latitude line $34^{\circ} 21^{\prime} 558^{\prime \prime}$ northern at the elevation level of 178 meters. The study region is known as Hyperthermic temperature regime (3) and semiarid climate (34) with the soil of Aridisols (containing saline or alkaline soils with low level of organic matter). Five genotypes of $\mathrm{F}_{2}$ tow-rowed barley (Hordeum vulgare L.) were used in these experiments which were named Local// Zanbaka (3//18), Local// ARTa/3/Avar (3//14), Local// Roho/Zanbaka (3//5), Local// Avar/H/Sout (3//1) and Local// Tadmor/Roho (3//4). The hybrid genotypes were obtained from a full diallel cross investigation by Mahmood (21) through crossing five varieties with a local variety in Garmian region, KRG, Iraq. The introduced varieties were developed by the International Centre for Agricultural Research in the Dry Areas (ICARDA) in Syria with different drought sensitivity. The site soil moisture regime was known as an aridic (Torric; irrigation is required for agricultural use) moisture regime $(2,17)$. Table 1 shows the distributions of total monthly rainfalls over both seasons (2016-17 and 2017-2018).

Table 1. The distributions of total yearly and monthly rainfalls $(\mathrm{mm})$ over both seasons (20162017 and 2017-2018).

\begin{tabular}{|ccccccccc|}
\hline Seasons & \multirow{2}{*}{ November } & \multirow{2}{*}{ December } & January & February & March & April & May & $\begin{array}{c}\text { Total } \\
(\mathbf{m m})\end{array}$ \\
\hline $\mathbf{2 0 1 6 - 2 0 1 7}$ & $\mathbf{2 1 . 0}$ & $\mathbf{2 9 . 4}$ & $\mathbf{2 5 . 4}$ & $\mathbf{1 9 . 4}$ & $\mathbf{1 2 2 . 8}$ & $\mathbf{6 . 3}$ & $\mathbf{1 . 8}$ & $\mathbf{2 2 6 . 1}$ \\
$\mathbf{2 0 1 7 - 2 0 1 8}$ & $\mathbf{1 5 . 7}$ & $\mathbf{0 . 0}$ & $\mathbf{2 3 . 2}$ & $\mathbf{1 6 5 . 4}$ & $\mathbf{0 . 0}$ & $\mathbf{7 5 . 1}$ & $\mathbf{8 . 0}$ & $\mathbf{2 8 7 . 4}$ \\
\hline
\end{tabular}

Experimental design and Statistical randomised block, split-plot design. Irrigation analysis: The experimental design was treatments (fully irrigated and unirrigated) 
were randomised on two main-plots. Genotypes were randomised on twenty subplots (5 rows x 4 columns; $1 \mathrm{~m}^{2}$ ) with four replicates (blocks) in each main plot. The irrigated treatments were complementary irrigated when required according to the severity of the drought in each season. GenStat 19th Edition (25) was used for statistical analysis of variance (ANOVA) by applying a split-plot design for both years and cross-year mean data. For making graphs and linear regressions, the GraphPad Prism 8.0.0 software package was used to calculate the relationships between related variables in both years and for the cross-year mean (13).

\section{Field measurements}

Canopy temperature depression $\left(\mathrm{CTd} ;{ }^{\circ} \mathrm{C}\right)$ : Crop canopy temperature was weekly recorded from anthesis (GS61) to ripening (GS89) from each plot for both years (2017-2018) using a hand-held infrared thermometer (Brannan Thermometer, Cleator Moor, Cumbria, UK). On each plot, the average of three readings of actual crop surface canopy temperature was measured remotely. Measurements were taken when the sky was clear and there was little or no wind and plant surfaces were dry, typically from 11:00h to 14:00h daily hours (24). The actual air temperature was repeatedly taken (after each ten readings). The canopy temperature depression was then calculated by the difference between actual crop canopy temperature and actual air temperature according to the equation below:

Canopy Temperature Depression

(CTd; ${ }^{\circ} \mathrm{C}$ )

\section{$=$ Actual Air Temperature}

- Actual Crop Canopy Temperature

\section{Leaf senescence parameters}

Flag-leaf senescence was visually assessed for each sub-plot in both years from anthesis (GS61) to full senescence twice a week using a visual senescence score chart ( 0 ; fully green and 10; fully senesced). Thermal time (average daily temperature $\left(0^{\circ} \mathrm{C}\right.$ base temperature $\left.)\right)$ was also calculated through measuring minimum and maximum daily temperature. The values of flag-leaf senescence were then fitted against thermal time (GS61; base temperature $0^{\circ} \mathrm{C}$ ) using logistic regression equation (25) as shown below:

$$
\mathbf{Y}=\frac{\mathbf{A}+\mathbf{C}}{(\mathbf{1}+\exp (-\mathbf{B} \times(\mathbf{X}-\mathbf{M})))}
$$

Where:

$Y$ is leaf senescence score; $X$ is thermal time from GS61; $A$ is the lower asymptote; $M$ is the thermal time for the point of inflection; $A+C$ is the upper asymptote; and $B$ is the slope at the point of inflection taken as the rate of senescence

The onset of leaf senescence (SEN ONSET $_{\text {) }}$ was taken as the thermal time (base temp. $0^{\circ} \mathrm{C}$ ) post-anthesis (GS61) at leaf visual senescence score 2 and end of leaf senescence (SEN $\left.\mathrm{END}_{\mathrm{END}}\right)$ as thermal time at leaf visual senescence score 9.5. Senescence durations $\left(\mathrm{SEN}_{\text {dur }}\right)$ were calculated by the difference between $\mathrm{SEN}_{\mathrm{END}}$ and SEN ONSET $_{\text {(28). }}$

\section{RESULTS AND DISCUSSION}

Canopy temperature depression $\left(\mathrm{CTd} ;{ }^{\circ} \mathrm{C}\right)$ : Canopy temperature depression was significantly affected by water stress and reduced by $0.53{ }^{\circ} \mathrm{C}$ in $2017(\mathrm{P}=0.007), 1.10{ }^{\circ} \mathrm{C}$ in $2018(\mathrm{P}=0.04)$, and $0.86{ }^{\circ} \mathrm{C}$ for the cross year mean $(\mathrm{P}=0.002)$. There was no significant difference between genotypes in 2017 $(\mathrm{P}=0.27)$. However, genotypes ranged from $2.82(3 / / 1)$ to $3.20{ }^{\circ} \mathrm{C}(3 / / 4)$ under irrigated conditions, and 1.65 (3//1) to $2.10{ }^{\circ} \mathrm{C}(3 / / 14)$ under unirrigated conditions $(\mathrm{P}=0.05)$. For the cross year mean, genotypes were in the ranges 2.97 (3//1) to $3.63{ }^{\circ} \mathrm{C}(3 / / 14)$ under irrigated conditions, and $2.23(3 / / 18)$ to $2.74{ }^{\circ} \mathrm{C}(3 / / 14)$ under unirrigated conditions $(\mathrm{P}=0.04)$. The irrigation $\mathrm{X}$ genotype interactions was significant in $2017(\mathrm{P}=0.04)$, but not for 2018 and averaging years, $(\mathrm{P}=0.15$ and $\mathrm{P}=0.06$, respectively; Table 2). 
Table 2. Analysis of variance summary for canopy temperature depression (CTd; $\left.{ }^{\circ} \mathrm{C}\right)$ for 5 barley genotypes under irrigation and unirrigated conditions in 2017, 2018 and cross-year mean.

\begin{tabular}{|c|c|c|c|c|c|c|}
\hline \multirow[t]{2}{*}{ Genotypes } & \multicolumn{2}{|c|}{2017} & \multicolumn{2}{|r|}{2018} & \multicolumn{2}{|c|}{ 2017-18 } \\
\hline & Irrigated & Unirrigated & Irrigated & Unirrigated & Irrigated & Unirrigated \\
\hline $3 / / 18$ & 4.13 & 2.60 & 3.05 & 1.85 & 3.59 & 2.23 \\
\hline $3 / / 14$ & 4.21 & 3.38 & 3.06 & 2.10 & 3.63 & 2.74 \\
\hline $3 / / 5$ & 3.23 & 2.93 & 2.83 & 2.00 & 3.28 & 2.46 \\
\hline $3 / / 1$ & 3.11 & 3.30 & 2.82 & 1.65 & 2.97 & 2.48 \\
\hline $3 / / 4$ & 3.51 & 3.33 & 3.20 & 1.85 & 3.36 & 2.59 \\
\hline $\begin{array}{l}\text { Mean } \\
\text { SED (df) }\end{array}$ & 3.64 & 3.11 & 2.99 & 1.89 & 3.36 & 2.50 \\
\hline $\begin{array}{l}\text { Year } \\
\text { Irrigation }\end{array}$ & & & & 0.330* & & \\
\hline Genotype & & & & 0.108* & & \\
\hline Irri. x Gen. & & & & $0.358^{\text {ns }}$ & & \\
\hline Year x Gen. & & & & & & \\
\hline
\end{tabular}

(SED) Standard error of differences of the means, (df) Degree of freedom, $(* * *) P<0.001,(* *) P<0.01,(*) P<0.05$ significance levels and (ns) not significant

Onset of leaf senescence (SENonset; ${ }^{\mathbf{0}} \mathrm{Cd}$ ): Drought significantly advanced leaf senescence by $54.6{ }^{\circ} \mathrm{Cd}$ in $2017(\mathrm{P}=0.01)$, $183.6{ }^{\circ} \mathrm{Cd}$ in $2018(\mathrm{P}=0.003)$, and $119.1{ }^{\circ} \mathrm{Cd}$ for the cross year mean $(\mathrm{P}=0.001)$. Genotypes ranged from 286.9 (3//5) to $346.9{ }^{\circ} \mathrm{Cd}$ (3//4) under irrigated conditions, and from 227.6 (3//5) to $281.9{ }^{\circ} \mathrm{Cd}$ (3//4) under unirrigated conditions in $2017 \quad(\mathrm{P}=0.02)$. In 2018, genotypes significantly differed from 362.6 (3//1) to $398.3{ }^{\circ} \mathrm{Cd}(3 / / 18)$ under irrigated, and from $177.8(3 / / 1)$ to $227.9{ }^{\circ} \mathrm{Cd}(3 / / 5)$ under unirrigated conditions $(\mathrm{P}=0.03)$. Averaging over years, genotypes ranged from $329.5(3 / / 1)$ to $365.4{ }^{\circ} \mathrm{Cd}(3 / / 4)$ and from 206.8 (3//18) to $247.8{ }^{\circ} \mathrm{Cd}(3 / / 14)$ under irrigated and drought conditions, respectively $(\mathrm{P}=0.04)$. The irrigation $\mathrm{x}$ genotype interaction was not significant in both years and cross year mean $(\mathrm{P}=0.86 ; \mathrm{P}=0.14$ and $\mathrm{P}=0.34$, respectively; Table 3). Regression analysis showed a significant positive relationship between canopy temperature depression and onset of leaf senescence in 2017 under unirrigated conditions $\left(\mathrm{R}^{2}=0.77 ; \mathrm{P}=0.05\right.$; Figure $\left.1 \mathrm{a}\right)$, but not under irrigated conditions. In 2018, the relationship was not significant under irrigated, but there was a trend for a positive correlation under unirrigated conditions $\left(\mathrm{R}^{2}=0.71 ; \mathrm{P}=0.07\right.$; Figure $\left.1 \mathrm{~b}\right)$. For the crossyear mean, a significant positive correlation was also found between canopy temperature depression and onset of leaf senescence under unirrigated conditions $\left(\mathrm{R}^{2}=0.89 ; \quad \mathrm{P}=0.02\right.$; Figure 1c), but not under irrigated conditions.

Table 3. Analysis of variance summary for onset of leaf senescence (SENonset; ${ }^{\circ} \mathrm{Cd}$ ) for 5 barley genotypes under irrigation and unirrigated conditions in 2017, 2018 and cross-year mean.

\begin{tabular}{|c|c|c|c|c|c|c|}
\hline \multirow[t]{2}{*}{ Genotypes } & \multicolumn{2}{|c|}{$\underline{2017}$} & \multicolumn{2}{|c|}{$\underline{2018}$} & \multicolumn{2}{|c|}{ 2017-18 } \\
\hline & Irrigated & Unirrigated & Irrigated & Unirrigated & Irrigated & Unirrigated \\
\hline $3 / / 18$ & 300.6 & 231.5 & 398.3 & 182.0 & 349.5 & 206.8 \\
\hline $3 / / 14$ & 323.9 & 281.3 & 377.7 & 214.3 & 350.8 & 247.8 \\
\hline $3 / / 5$ & 286.9 & 227.6 & 390.9 & 227.9 & 338.9 & 227.8 \\
\hline $3 / / 1$ & 296.4 & 259.5 & 362.6 & 177.8 & 329.5 & 218.7 \\
\hline $3 / / 4$ & 346.9 & 281.9 & 384.0 & 193.2 & 365.4 & 237.5 \\
\hline Mean & 310.9 & 256.3 & 382.7 & 199.1 & 346.8 & 227.7 \\
\hline \multicolumn{7}{|l|}{$\underline{\text { SED (df) }}$} \\
\hline Year (1) & & & & & \multicolumn{2}{|c|}{$16.72^{\mathrm{ns}}$} \\
\hline Irrigation (1) & \multicolumn{2}{|c|}{$9.19 * *$} & \multicolumn{2}{|c|}{$21.54 * *$} & \multicolumn{2}{|c|}{$11.71 * * *$} \\
\hline Genotype (4) & \multicolumn{2}{|c|}{$17.75^{*}$} & \multicolumn{2}{|c|}{$11.22 *$} & \multicolumn{2}{|c|}{$10.50 *$} \\
\hline Irri. x Gen. (4) & \multirow{2}{*}{\multicolumn{2}{|c|}{$24.25^{\text {ns }}$}} & \multicolumn{2}{|c|}{$25.79^{\mathrm{ns}}$} & \multicolumn{2}{|c|}{$17.70^{\mathrm{ns}}$} \\
\hline Year x Gen. (4) & & & & & \multicolumn{2}{|c|}{$21.35 * *$} \\
\hline
\end{tabular}


a) 2017

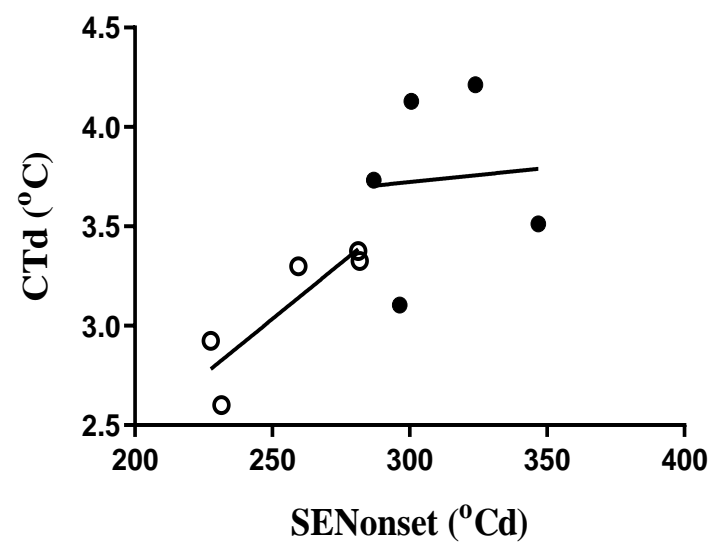

c) 2017-18 b) 2018

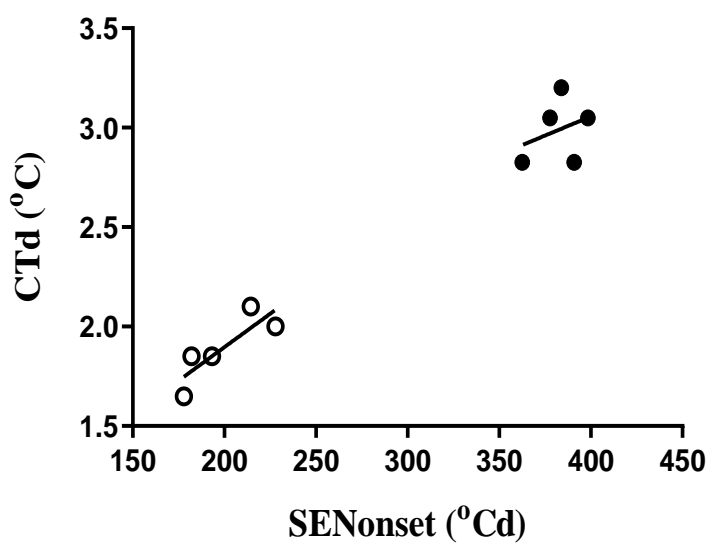

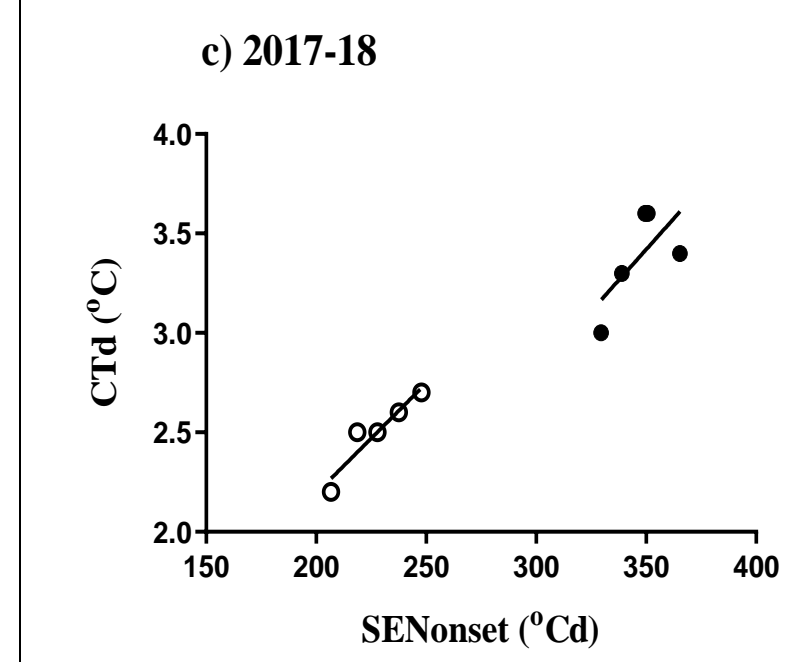

$\rightarrow$ Irrigated

a) $Y=0.001 * X+3.297$

$R^{2}=0.01 ; P=0.90$

b) $Y=0.004^{*} X+1.513$

$R^{2}=0.10 ; P=0.60$

c) $Y=0.012 * X-0.915$

$R^{2}=0.45 ; P=0.21$

$$
\begin{aligned}
& \theta \text { Unirrigated } \\
& Y=0.011^{\star} X+0.218 \\
& R^{2}=0.77 ; P=0.05 \\
& Y=0.007^{\star} X+0.551 \\
& R^{2}=0.71 ; P=0.07 \\
& Y=0.011^{\star} X-0.021 \\
& R^{2}=0.89 ; P=0.02
\end{aligned}
$$

Figure 1. Linear regressions of onset leaf senescence (SENonset; ${ }^{\circ} \mathrm{Cd}$ ) on canopy temperature depression (CTd; ${ }^{\circ} \mathrm{C}$ ) for 5 genotypes of barley in (a) 2017, (b) 2018 and (c) cross-year mean under irrigated and unirrigated conditions

\section{End of leaf senescence (SENend; ${ }^{\mathbf{0}} \mathrm{Cd}$ )}

There was no significant effect of drought on advancing end of leaf senescence in 2017 $(\mathrm{P}=0.13)$. However, water stress fastened the end of leaf senescence by $104.8{ }^{\circ} \mathrm{Cd}$ in 2018 and $70.9{ }^{\circ} \mathrm{Cd}$ averaging over years $(\mathrm{P}=0.05$ and $\mathrm{P}=0.01$, respectively). In 2017, genotypes ranged from 629.5 (3//18) to $704.5{ }^{\circ} \mathrm{C}(3 / / 14)$ under irrigated conditions, and 583.8 (3//18) to $679.0{ }^{\circ} \mathrm{C}(3 / / 1)$ under unirrigated conditions $(\mathrm{P}=0.004)$. For the cross year mean, genotypes did not significantly differed $(\mathrm{P}=0.34)$. However, in 2018, genotypes were in the ranges $690.2(3 / / 14)$ to $733.5{ }^{\circ} \mathrm{C}(3 / / 18)$ under irrigated conditions, and 567.7 (3//1) to 632.8 ${ }^{\circ} \mathrm{C}$ (3//18) under unirrigated conditions
$(\mathrm{P}=0.03)$. The irrigation $\mathrm{x}$ genotype interactions were significant in both years (2017 and 2018) and averaging over years $(\mathrm{P}=0.003, \mathrm{P}=0.002$ and $\mathrm{P}=0.04$, respectively; Table 4). Linear regressions showed that there was no correlation between canopy temperature depression and end of leaf senescence amongst genotypes under irrigated conditions in both years and the cross year mean. However, a trend for a positive relationship was found under unirrigated conditions $\left(\mathrm{R}^{2}=0.39 ; \mathrm{P}=0.26\right.$; Figure $\left.2 \mathrm{a}\right)$ in 2017. The correlation in 2018 was more close to be significant $\left(\mathrm{R}^{2}=0.59 ; \mathrm{P}=0.13\right.$; Figure $\left.2 \mathrm{~b}\right)$ than cross year mean $\left(\mathrm{R}^{2}=0.22 ; \mathrm{P}=0.43\right.$; Figure 2c) under drought. 
Table 4. Analysis of variance summary for end of leaf senescence (SENend; ${ }^{\circ} \mathrm{Cd}$ ) for 5 barley genotypes under irrigation and unirrigated conditions in 2017, 2018 and cross-year mean.

\begin{tabular}{|c|c|c|c|c|c|c|}
\hline \multirow[t]{2}{*}{ Genotypes } & \multicolumn{2}{|c|}{$\underline{2017}$} & \multicolumn{2}{|c|}{$\underline{2018}$} & \multicolumn{2}{|c|}{ 2017-18 } \\
\hline & Irrigated & Unirrigated & Irrigated & Unirrigated & Irrigated & Unirrigated \\
\hline 3//18 & 629.5 & $\begin{array}{l}583.8 \\
\end{array}$ & 733.5 & 632.8 & 681.5 & 608.3 \\
\hline $3 / / 14$ & 704.5 & 618.0 & 690.2 & 623.5 & 697.3 & 620.7 \\
\hline $3 / / 5$ & 648.4 & 631.9 & 694.9 & 623.1 & 671.6 & 627.5 \\
\hline $3 / / 1$ & 642.4 & 679.0 & 722.1 & 567.7 & 682.3 & 623.4 \\
\hline $3 / / 4$ & 700.0 & 627.0 & 727.0 & 596.2 & 713.5 & 611.6 \\
\hline Mean & 664.9 & 627.9 & 713.5 & 608.7 & 689.2 & 618.3 \\
\hline \multicolumn{7}{|l|}{$\underline{\operatorname{SED}(\mathrm{df})}$} \\
\hline Year & \multirow{2}{*}{\multicolumn{2}{|c|}{$17.93^{\text {ns }}$}} & & & \multicolumn{2}{|c|}{$14.08^{\mathrm{ns}}$} \\
\hline Irrigation & & & \multicolumn{2}{|c|}{$34.15^{*}$} & \multicolumn{2}{|c|}{$19.29 *$} \\
\hline Genotype & \multicolumn{2}{|c|}{$15.08^{* * *}$} & \multicolumn{2}{|c|}{ 11.06* } & \multicolumn{2}{|c|}{$9.35^{\mathrm{ns}}$} \\
\hline Irri. x Gen. & \multirow{2}{*}{\multicolumn{2}{|c|}{$26.18^{* *}$}} & \multirow{2}{*}{\multicolumn{2}{|c|}{$36.90 * *$}} & \multicolumn{2}{|c|}{$22.62 *$} \\
\hline Year x Gen. & & & & & \multicolumn{2}{|c|}{$18.39 * *$} \\
\hline
\end{tabular}

(SED) Standard error of differences of the means, (df) Degree of freedom, $\left(^{* * *}\right) P<0.001,\left({ }^{* *}\right) P<0.01,\left(^{*}\right) P<0.05$ significance levels and (ns) not significant

a) 2017

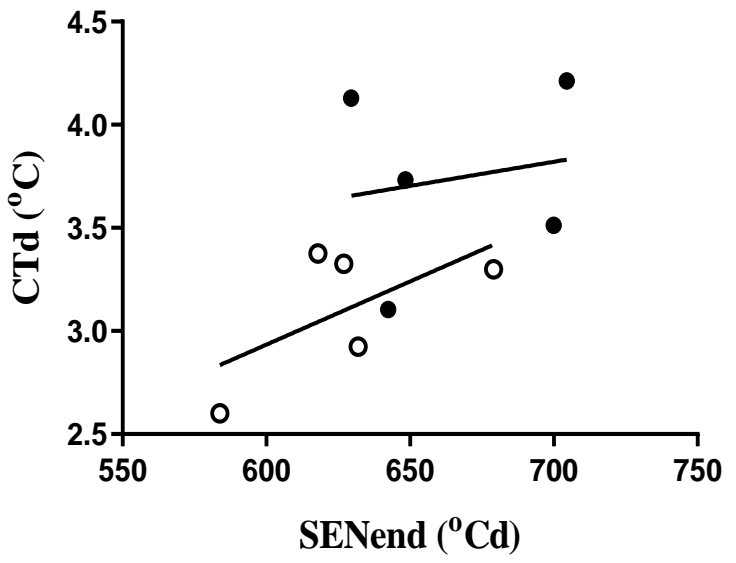

c) $2017-18$

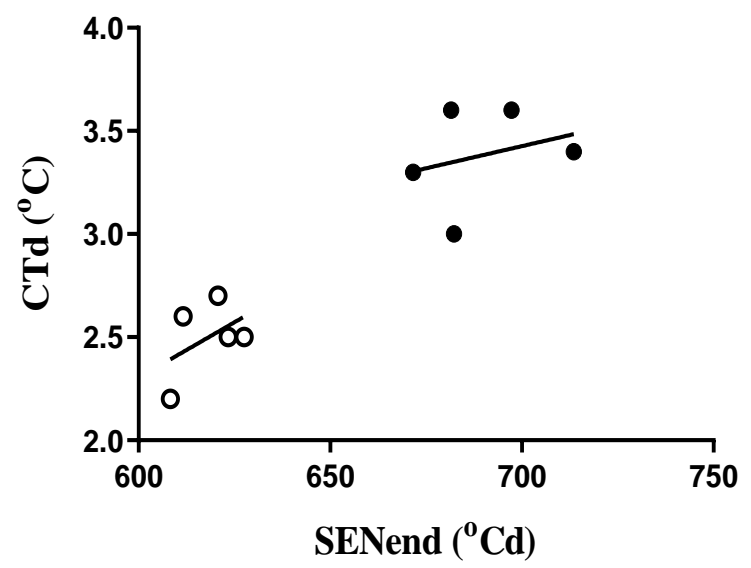

b) 2018

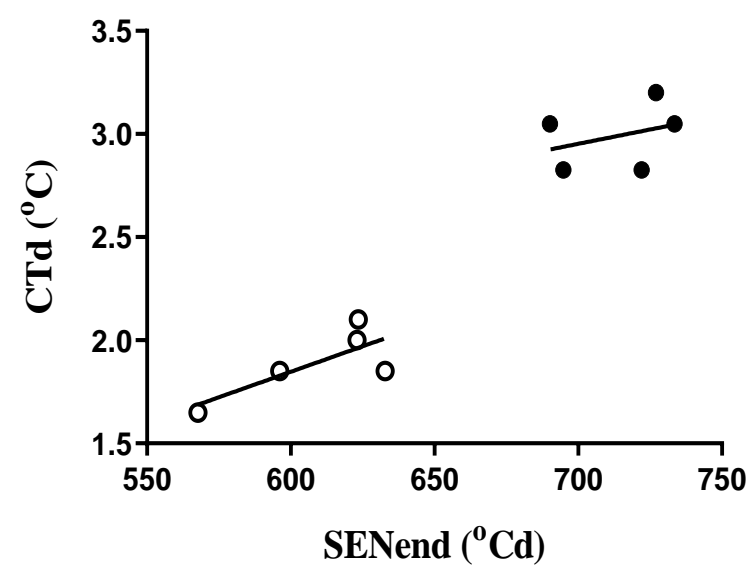

$\rightarrow$ Irrigated

- Unirrigated

a) $Y=0.002^{*} X+2.182$

$Y=0.006^{*} X-0.743$

$R^{2}=0.03 ; P=0.77$

$R^{2}=0.39 ; P=0.26$

b) $Y=0.003^{*} X+1.008$

$Y=0.005^{\star} X-1.119$

$R^{2}=0.11 ; P=0.58$

$R^{2}=0.59 ; P=0.13$

c) $Y=0.004^{*} X+0.42$

$Y=0.010^{*} X-4.149$

$R^{2}=0.08 ; P=0.65$

$R^{2}=0.22 ; P=0.43$

Figure 2. Linear regressions of end leaf senescence (SENend; ${ }^{\circ} \mathrm{Cd}$ ) on canopy temperature depression (CTd; ${ }^{\circ} \mathrm{C}$ ) for 5 genotypes of barley in (a) 2017, (b) 2018 and (c) cross-year mean under irrigated and unirrigated conditions 


\section{Genotype logistic leaf senescence}

Genotypes were different in response to the effect of drought on post-anthesis leaf senescence in $2018(\mathrm{P}=0.05)$. Genotypes 3//18, $3 / / 1$ and $3 / / 4$ were generally appeared to be more affected than the genotypes $3 / / 14$ and $3 / / 5$ (figure 3). At the first half of leaf

(a) $3 / / 18$

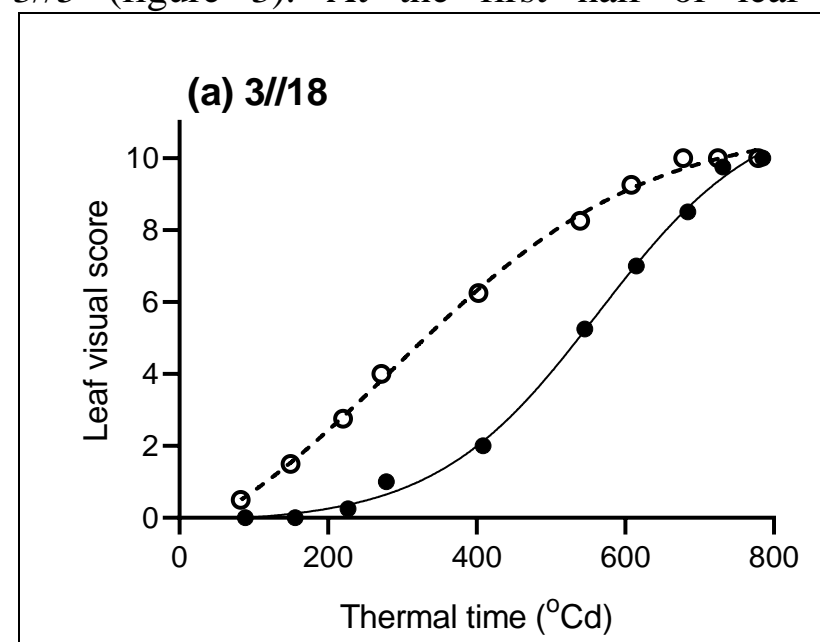

(c) $3 / / 5$

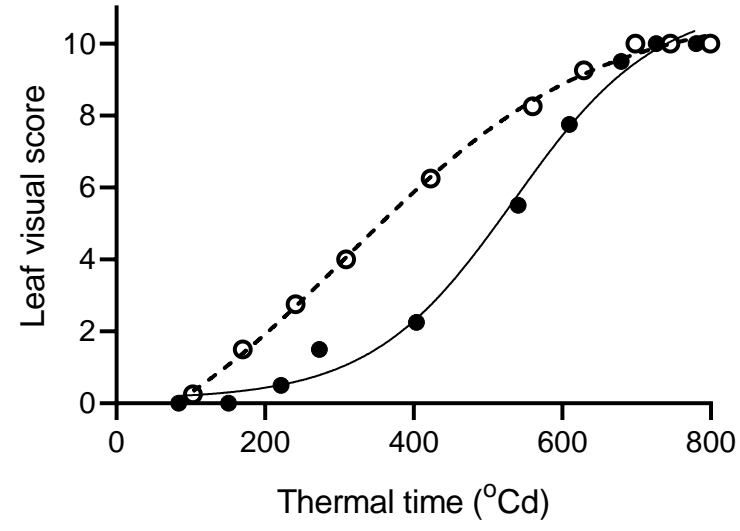

(e) $3 / / 4$

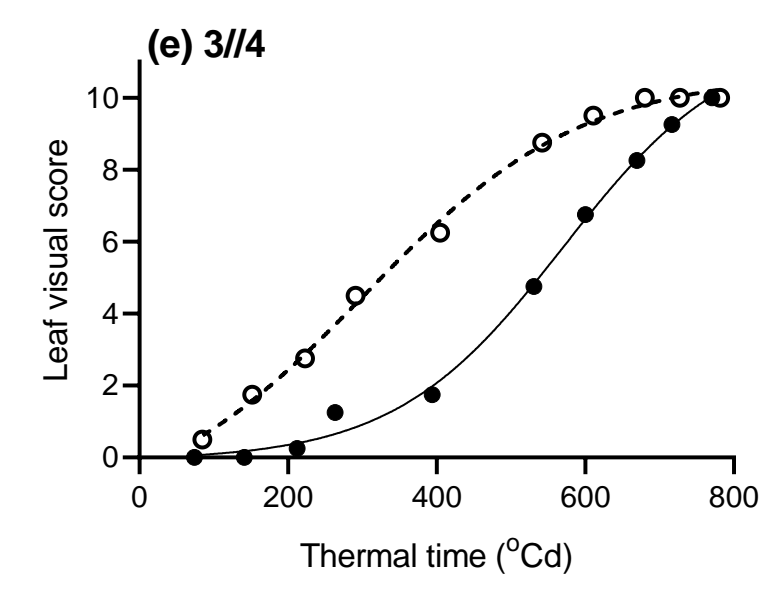

senescence, genotype $3 / / 18$ was the most affected than the other genotypes (figure 3a). However, genotype 3//1 reached the end of leaf senescence earlier than the other genotypes (figure 3d). Genotype $3 / / 5$ was generally the least affected comparing to others (figure $3 \mathrm{c}$ ).

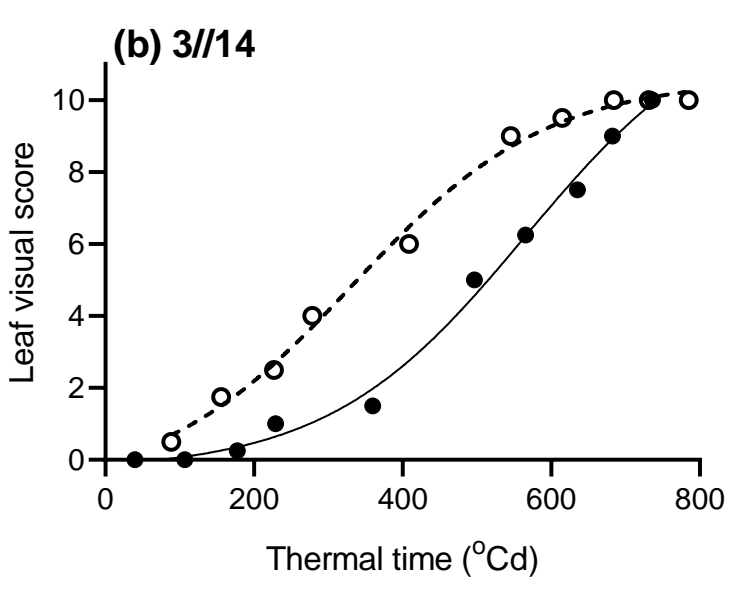

(d) $3 / / 1$

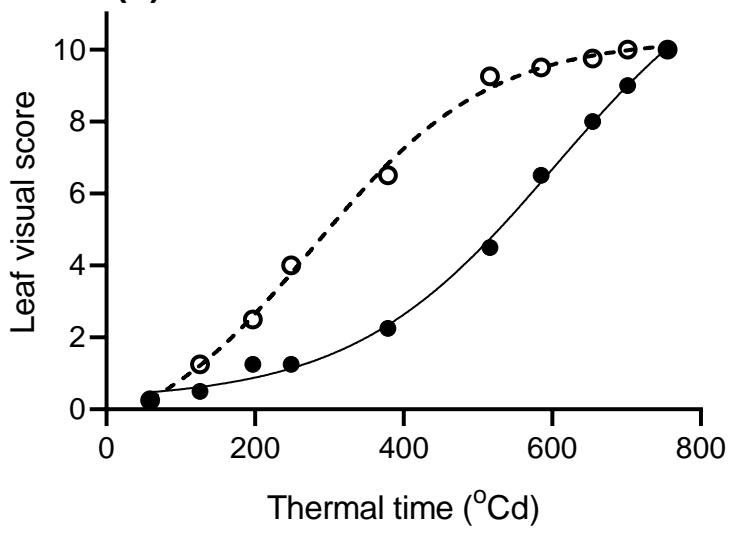

-- Irrigated

-๑. Unirrigated

Figure 3. Nonlinear regressions (logistics) of post-anthesis thermal time $\left({ }^{\circ} \mathrm{Cd}\right)$ on flag-leaf senescence visual score for 5 genotypes of barley: (a) 3//18, (b) 3//14, (c) 3//5, (d) 3//1 and (e) $3 / / 4$ under irrigated and unirrigated in 2018

The roles of stay-green traits under drought conditions have been reported in different crops such as sorghum, maize, wheat and barley, to be associated with greater yield production and longer green canopy duration $(6,8,12,32)$. In the present study, drought 
raised canopy temperature by almost one degree Celsius on average of both years. Leaf senescence durations were different amongst genotypes in both experiments, and water stress advanced SENonset by around $34 \%$ and SENend by around $10 \%$ averaging over years. This is consistent with previous works that stay-green traits are potentially affected by water stress $(14,32,35)$. Post-anthesis canopy temperature depression was positively correlated with onset of leaf senescence, and cooler canopies had a later onset of leaf senescence amongst genotypes averaging across years. This relationship might be associated with increasing water-use efficiency and/or water uptake through a deeper root system (20). However, there was a trend for a positive relationship between canopy temperature and the end of leaf senescence in 2018 , this may due to the role of gene control for the end of leaf senescence (35). Thus, canopy temperature could be a useful indicator of drought tolerant genotypes, and low canopy temperature can be associated with the genotype capability of water extract through a deeper root system and/or water-use efficiency of genotypes under drought (18, 29). Early flowering may indirectly delay $\mathrm{N}$ remobilization and prolong leaf senescence as a result of reducing pre-anthesis $\mathrm{N}$ uptake (4). Results in this study indicate that canopy temperature and leaf senescence traits can be important selection criterions for stressadapted genotypes under drought environments in breeding programs.

\section{CONCLUSIONS}

Results in this study clearly showed significant impact of water stress on leaf senescence and canopy temperature in barley. Genotypes responded to water limited conditions from high to low sensitivity in terms of canopy temperature and leaf senescence in both experiments due to genetic variations between genotypes as stated in the objectives in this study. The associations between cooler canopies and later onset of leaf senescence in this experiment appeared to be linked to genotype potential of extracting water from deeper soil layers through a deeper rooting system. These indices, therefore, could be used as a selection tool in breeding programs to identify water stressed tolerant genotypes in this region.

\section{REFERENCES}

1. Adamo N., A. Nadhir, S. Varoujan, K. Sven, and L. Jan. 2018. Climate Change: Consequences on Iraq's Environment. Journal of Earth Sciences and Geotechnical Engineering. 8, 3, 43-58

2. Al-Taie, F. H.; C. Sycand and J. Stoops 1969. Soil groups of Iraq, their classification and characteristics-pedologie, 19:65-148

3. Aziz, S. N. 2006. Survey and classification of some soils from Kurdistan region. M.Sc. thesis submitted to the University of Sulaimani, college of agriculture

4. Bogard M, M, Jourdan V, Allard P, Martre M. R,Perretant C, Ravel E, Heumez, S, Orford J, Snape, S, Griffiths, O, Gaju, J, Foulkes and Le J. Gouis 2011. Anthesis date mainly explained correlations between post-anthesis leaf senescence, grain yield, and grain protein concentration in a winter wheat population segregating for flowering time QTLs. Journal of Experimental Botany 62, 3621-3636

5. Brennan J, A, Condon Van M, Ginkel and M. Reynolds 2007. An economic assessment of the use of physiological selection for stomatal aperture-related traits in the CIMMYT wheat breeding programme. Journal of Agricultural Science-Cambridge- 145, 187

6. Borrell A.K, and G.L.Hammer 2000. Nitrogen dynamics and the physiological basis of stay-green in sorghum. Crop Science 40, 1295-1307

7. Campiglia E, R, Mancinelli De E, Stefanis S, Pucciarmati and E. Radicetti 2015. The long-term effects of conventional and organic cropping systems, tillage managements and weather conditions on yield and grain quality of durum wheat (Triticum durum Desf.) in the Mediterranean environment of Central Italy. Field Crops Research 176, 34-44

8. Campos H, A, Cooper J. E, Habben G. O,Edmeades and J. R.. Schussler 2004. Improving drought tolerance in maize: a view from industry. Field Crops Research 90, 19-34 9. Cattivelli L, F, Rizza F.W, .Badeck E, Mazzucotelli A. M, Mastrangelo E, Francia C, Mare A, Tondelli and A. M.Stanca 2008. Drought tolerance improvement in crop plants: An integrated view from breeding to genomics. Field Crops Research 105, 1-14 
10. Dimova, D., Valcheva, D., S. Zapranov and G. Mihova, 2006. Ecological plasticity and stability in the yield of winter barley varieties, Jubilee conference 65 years agrarian science in Dobrudzha. Field Crop Studies, 3 (2): 197-203

11. Fischer RA, and R. Maurer 1978. Drought Resistance in Spring Wheat Cultivars. I Grain Yield Responses. Australian Journal of Agricultural Research 29, 897-912

12. Foulkes M.J, J.W, Snape V.J, Shearman and R. Sylvester-Bradley 2007. Physiological processes associated with winter wheat yield potential progress. Wheat Production in Stressed Environments 12, 591-597

13. GraphPad Prism Version 8.0.0 for Windows 2019. Linear regression analysis was performed using graphPad Software, San Diego, California USA, www.graphpad.com

14. Gous, P. W., F.Warren, R. Gilbert, and G. P. Fox, 2017. Drought-Proofing Barley (Hordeum vulgare): The Effects of Stay Green on Starch and Amylose Structure. CCHEM, 94: 873-880

15. Guiboileau A, R, Sormani C, Meyer and C. Masclaux-Daubresse 2010. Senescence and death of plant organs: nutrient recycling and developmental regulation. Comptes rendus biologies 333, 382-391

16. Hassan, H., M., Mohammed, and Y. Mahmood, 2019. Association between some grain related traits of barley under drought and irrigated conditions, Journal of University of Garmian, 6(SCAPAS Conference), pp. 76-83. doi: 10.24271/garmian.scpas10

17. Kassim, J. K.; K. Z. Al-Janabi and M. I. Karim 1989. Soil temperature regimes in Iraq: II-Relationships between soil temperature and latitude, longitude and elevation. J. Agri. Water Reso. Res. 8(1):111-121

18. Kumar J, R.; and S. Nayak, 2010. Gene pyramiding-A broad spectrum technique for developing durable stress resistance in crops. Biotechnol. Mol. Biol. Rev. 5, 51-60

19. Linear regression analysis was performed using GraphPad Prism version 8.0.0 for Windows 2019. GraphPad Software, San Diego, California USA, www.graphpad.com

20. Lopes MS, and M. P. Reynolds 2012. Stay-green in spring wheat can be determined by spectral reflectance measurements (normalized difference vegetation index) independently from phenology. Journal of Experimental Botany 63, 3789-3798

21. Mahmood, Y. A. 2010. Full Diallel Crosses in Two-rowed Barley (Hordeum vulgare L.). M.Sc. thesis submitted to the University of Sulaimani, college of agriculture 22. Mahmood Y. A., H., Hassan, and M., Mohammed, 2019. A physiological explanation of drought effect on flag-leaf specific weight and chlorophyll content of barley. Iraqi Journal of Science 60 (12), 25312539

23. Mir R, M, Zaman-Allah N, Sreenivasulu R, Trethowan and R. Varshney 2012. Integrated genomics, physiology and breeding approaches for improving drought tolerance in crops. Theoretical and Applied Genetics 125, 625-645

24. Pask A.J.D, J, Pietragalla, D.M, Mullan, and M. P. Reynolds 2012. Physiological Breeding II: A Field Guide to Wheat Phenotyping. Mexico, D.F: CIMMYT

25. Payne R, S, Harding D, Murray D, Soutar D, Baird A, Glaser S, Welham A, Gilmour R, Thompson and R. Webster 2012. A guide to regression, nonlinear and generalized linear models in GenStat ${ }^{\circledR}$. VSN International: Hemel Hempstead, UK

26. Rahimizadeh M, A, Kashani A, ZareFeizabadi, A. R, Koocheki,. And M. NassiriMahallati 2010. Nitrogen use efficiency of wheat as affected by preceding crop, application rate of nitrogen and crop residues. Australian Journal of Crop Science 4, 363-368 27. Reynolds M, F, Dreccer,. And R.Trethowan 2007. Drought-adaptive traits derived from wheat wild relatives and landraces. Journal of Experimental Botany 58, 177-186

28. Roghzai, Y. A. M. 2016. The physiological and genetic bases of drought tolerance in bread wheat and ancestral wheat species. $\mathrm{PhD}$ thesis submitted to the University of Nottingham, school biosciences, crop and plant scieces department

29. Sallam, A.; A. M.; Alqudah, M.F.A.; Dawood, P. S.; Baenziger, and A. Börner, 2019. Drought Stress Tolerance in Wheat and Barley: Advances in Physiology, Breeding and Genetics Research. Int. J. Mol. Sci., 20, 3137

30. Slack, S., L. M., York, Y., Roghazai, Y., Lynch, M., Bennett, and J. Foulkes, 2018. 
Wheat shovelomics II: Revealing relationships between root crown traits and crop growth. BioRxiv 280917;

doi:

https://doi.org/10.1101/280917

31. Tuberosa R, and S. Salvi 2006. Genomicsbased approaches to improve drought tolerance of crops. Trends in Plant Science 11, 405-412

32. Vaezi B, V, Bavei, B. Shiran 2010. Screening of barley geno-types for drought tolerance by agro-physiological traits infield condition. Afr J Agric Res 5:881-892
33. Verma V, M. J, Foulkes A. J, Worland R, Sylvester-Bradley, P.D.S,Caligari, J. W. Snape 2004. Mapping quantitative trait loci for flag leaf senescence as a yield determinant in winter wheat under optimal and droughtstressed environments. Euphytica 135, 255263

34. Walter, H. and H. Leith, 1960. Climadigram welt atlas. Jena, 4: 434

35. Wehner, G.; C.; Balko, K.; Humbeck, K.; Zyprian, and F. Ordon, 2016. Expression profiling of genes involved in drought stress and leaf senescence in juvenile barley. BMC Plant Biol., 16, 3. 